\title{
The Political Economy of Unmediated Democracy:
}

\section{Italian Austerity under Mario Monti}

\author{
Pepper D. Culpepper \\ European University Institute \\ Via dei Roccettini, 9 \\ 50014 San Domenico di Fiesole (FI) \\ Italy \\ Telephone: +390554685286 \\ Email: pepper.culpepper@eui.eu
}

May 2014

Forthcoming in West European Politics

Word Count: 8367

\begin{abstract}
This article explores the political economy of reform under the technocratic government of Mario Monti. Unlike the technocratic governments of the 1990s, the Monti interregnum was an experiment in unmediated democracy, in which a government is actively supported neither by political parties nor by encompassing social groups. Italian political leaders adopted unmediated democracy because of the underlying interest group conflicts in the Italian political economy. Unmediated democrats such as Monti can impose bitter medicine on a stalemated society when it is in a stage of acute crisis, but the passage of longer-term reforms requires a social coalition to support those reforms beyond the critical stage of crisis. Thus the government implemented budget cuts, but liberalisation and institutional reform stalled in the face of opposition. Italy is unlikely to be durably reformed by a government that is not anchored to society through political parties or interest groups.
\end{abstract}


'This country needs reforms, not elections.'

EU President Herman van Rompuy, speaking in Italy shortly before the appointment of Mario Monti as unelected prime minister in November 2011

Mario Monti took the reins of the Italian government at the depths of the eurozone crisis in 2011, when Italy's cost of borrowing on international markets had reached unsustainable levels. Monti, a former European commissioner for competition policy, was hailed as a saviour not only in Italy, but also in European capitals and by his former colleagues in Brussels. Monti took over as premier from the fallen Silvio Berlusconi, whose fiddling in Rome was widely judged as incapable of saving Italy from bankruptcy and the eurozone from the break-up that Italian insolvency might have brought in its wake. Italy was too big to bail out; Italy required economic reforms. This was the mantra of the European elite, and Monti's popularity at home upon taking office suggested that the Italian public shared this view.

Just over one year later, European elites continued to support Monti and his reform plan. Italians, however, emphatically rejected Monti's newly formed political party at the polls. The election of February 2013 resulted in a country split three ways - with 30 per cent of voters choosing the coalition of the centre-left, 30 per cent choosing the coalition of the centre-right, and 25 per cent voting for the party of Beppe Grillo, a comedian-turned-blogger whose Five Star Movement ran against Monti's technocratic record and the parties of the mainstream right and left. Having received just over 10 per cent of the vote, the centrists who had run with Monti had not gained enough seats to be a viable coalition partner in a future government. 
This article considers the political economy of reform under Monti: the coalitional dynamics of the Italian political economy and the government's strategy for passing economic reforms in these circumstances. Monti's government is typically described as technocratic - composed of non-politicians who were in government to solve the acute problems facing the country before turning it back over to elected politicians (McDonnell and Valbruzzi 2014). The choice of a technocratic government to solve big Italian problems was not unprecedented. In the 1990s, the governments of Carlo Azeglio Ciampi and Lamberto Dini both governed as technocrats to pass what were regarded as 'necessary' reforms of budgets, pensions, and electoral and government institutions (Pasquino and Valbruzzi 2012: 619). Indeed, Schmidt and Gualmini (2013) argue that Monti's appointment simply replicated the Italian trend of alternating periods of opportunistic partisan governments with pragmatic technocratic ones. This article contends instead that the Monti experiment was a radical departure even from previous technocratic Italian governments.

The technocratic governments of the 1990s worked closely with the social partners, particularly labour unions, in order to achieve their reforms, often through negotiated social pacts. The literature on social pacts demonstrated that the cooperation of the unions with these governments enhanced the problem-solving capacity of these fragile governments, giving them both a greater capacity to mobilise social consent and a more informed view of the barriers to implementing successful reform (Rhodes 1998; Culpepper 2002; Baccaro and Lim 2007). Recent scholarship has shown that the problem-solving capacity of the technocratic governments was a joint product of the support of parties of the left and of labour unions, and that unions used their role in designing reform to deflect some of the costs for their members 
(Simoni 2010; Barta 2011). Even more so than partisan governments, Italian technocratic reformers of the 1990s were tightly linked to the organisations of Italian society.

The Monti government emphatically rejected this strategy of reform. Instead, it tried to develop policies autonomously, with little consultation of unions, organised employers, or political parties. In other words, the unelected Monti government attempted to impose an austerity plan without relying on any relays to Italian society to mobilise consent for its difficult reform programme. The Monti interregnum was an experiment in unmediated democracy, which I define as a government actively supported neither by political parties that have won democratic election nor by an encompassing coalition of social groups with the legitimacy and authority to represent large functionally defined groups within society. ${ }^{1}$ In other words, unmediated democracy is a situation in which neither political partisanship nor corporatist intermediation connects a government to the society on whose behalf it is adopting reforms. $^{2}$

In this article I demonstrate how the structure of the Italian political economy and politics led to the emergence of unmediated democracy in 2011. Italian technocratic governments of the 1990s had relied on a temporary unity of purpose between employers, unions, and the political left. It was an ungainly coalition, one that did not survive its internal centrifugal pressures. But given the evolution of the Italian economy, such a societally anchored reform coalition was not available to cope with the crises confronted by the Monti government at the end of 2011. Italy is not the only country in the new periphery of the eurozone that faces the challenges of strong international pressures for reform and a strongly entrenched opposition to such reform at the domestic level. Yet it was the only country to adopt this experiment in 
unmediated democracy. The Italian experience may therefore shed some light on the possibilities and limitations of such a strategy for adopting unpopular retrenchment programmes during an economic crisis.

\section{Unmediated Democracy}

Political parties and secondary associations are the primary forms of participation that link government to society in the rich democracies. Parties have long had to fulfil the dual function of both providing government policy that represents their electoral constituencies and respecting the economic constraints imposed by the global economy (Mair 2009). Partisan governments with a governing majority can adopt reforms either by convincing their reluctant members to go along or by trying to shift losses onto their opponents ( $c f$. Garrett 1993). During the 1990s, many governments that had to adopt significant reform plans but lacked such partisan support used social pacts, involving the preeminent functional organisations of unions and employers' associations, to develop such reforms. These governments employed negotiation with the social partners to legitimise their changes to the social contract of postwar capitalism (Regini 2000; Avdagic 2010).

Italy has experienced both pacted and partisan reform during the past two decades. The social pacts of the 1990s saw unions and employers, together with representatives of technocratic governments, negotiate institutional reforms that abolished the old system of wage indexation (1992), introduce a new system of wage bargaining (1993), and adopt substantial reforms of the pension system $(1992,1995)$ (Rhodes 1998; Culpepper 2008). These sweeping reforms were achieved by weak governments (those without a partisan majority) which relied on unions to provide 
them with political cover to put in place such important economic adjustments (Regini 2000; Baccaro and Lim 2007). The left government of Romano Prodi, which was elected in 1996, followed the technocratic governments of Dini by relying on unions to develop labour-market reforms (Simoni 2010; Schmidt and Gualmini 2013).

The centre-right coalition under Berlusconi, elected in 2001, showed that Italian pension reform need not be a product of negotiations with the social partners. Although the Berlusconi government negotiated with unions and employers, both groups were largely shut out of the 2004 pension reform, which Natali and Rhodes (2005: 186) called 'the end of corporatist welfare policy-making all'italiana.' Instead, the key compromises of the 2004 pension reform were the product of negotiation between political parties in the coalition, with the Northern League defending the seniority pension rights of its northern voters, while the National Alliance and UDC included protections for the disability and public sector benefits of their electorates in the south of the country (Natali and Rhodes 2005). The reform's transition to a multipillar system with supplementary pensions went in the direction favoured by the bank and insurance companies that supported the centre-right government, even though unions called two general strikes over the course of negotiations (Jessoula and Alti 2010: 174). In short, the 2004 pension reform was a product of the interests represented by the political parties in government rather than by the social partners.

A government practicing unmediated democracy breaks with both of these paths to social legitimation. Such a government relies on parties and their elected representatives not to topple them by withdrawing parliamentary confidence in the government, but it simultaneously renounces the use of the political party as a device to build legitimacy. It justifies this choice by reference to economic constraints or international commitments, rather than using a party apparatus to build social support 
for it (Karremans 2014). In similar fashion, it does not rely on shoring up its social support by including large interest groups, such as unions or employers' associations, in the making of reform policies. This allows the government to develop policy solely with an eye towards its own objectives, but it also deprives that government of the ability to share the responsibility for what are likely to be unpopular policies in a time of austerity. To such a government, it is clear what must be done - that which is required to restore solvency and the ability to borrow on international markets at reasonable rates - and it requires no justification other than the need to do this and to share the pain of doing so across society.

It might well be asked whether such governments are democratic at all. Two features allow unmediated democracies to claim the same mantle of democratic legitimacy accorded to party governments. The first is that they are still subject to the will of previously elected parties, which support them in parliament. The Monti government, for example, was supported by the parties of left and right, with only the Northern League in opposition. It would eventually fall when the centre-right party withdrew its support. Second, and in some tension with the first, is the court of popular opinion. If there is widespread agreement in the populace that reforms are necessary, whether because of economic pressure or international obligations, this support bolsters the legitimacy of the unmediated democratic government vis-à-vis parliamentary parties. In this sense, the unmediated democratic government appears to stand in the same relation to elected governments as populist governments. In fact, though, the two phenomena are mirror images of one another. Populist parties are anti-elite movements whose simple solutions make them popular with the public until they run into the world of complex problems. Unmediated democratic governments are elite non-movements whose ability to cope with complex problems means that 
parties and the public are willing to turn to them until crisis abates, when the fundamental unpopularity of austerity will doom them at the ballot box.

Some might argue that unmediated democracy is really the only choice Italy had, given the international constraints facing the government that took office in November 2011. And they might point to the Greek government that took office the same month, led by technocrat Lucas Papademos, as representing an equivalent phenomenon. That would be a misunderstanding of the radical character of Monti's project in unmediated democracy. As pointed out in the analysis of Duncan McDonnell and Marco Valbruzzi (2014), although the governments in Greece and Italy were both led by technocratic prime ministers, their internal composition was entirely different. Monti's government included no representatives of political parties. Papademos' cabinet was primarily composed of representatives of the two largest parties of the centre-right and centre-left, New Democracy and PASOK. Indeed, twelve of the eighteen ministers in the Papademos government had been PASOK ministers in the previous partisan government. McDonnell and Valbruzzi conclude that the 'Papademos government can thus be seen as a temporary oversized coalition of the largest parties, led by a technocrat' (2014: 6). The Greek solution to the demands of austerity was a grand coalition, not unmediated democracy. The other members of the new 'Eurozone periphery' - Ireland, Portugal, and Spain - also chose to adopt reforms with partisan or grand coalition governments, not governments deliberately divorced from the societies they were charged with reforming (Armingeon and Baccaro 2012). ${ }^{3}$

Italian political leaders adopted austerity reforms through a system of unmediated democracy because of the underlying interest group conflicts in the Italian political economy. Italy faced pressing international demands for budgetary 
retrenchment against a background of internal factiousness. Scholars writing about Italy, and particularly Italy under Silvio Berlusconi, tend to emphasise the fecklessness of political leaders to account for the glacial pace of political change since entering the eurozone (Pasquino 2007; Schmidt and Gualmini 2013). The choice of the sober professor Monti to replace the billionaire playboy Berlusconi fits the optics of this narrative. Yet whatever their personal qualities, all Italian leaders face a structural situation of a sharply divided country. Unmediated democracy offered a way around this blocked society by trying to ignore it, but the character of this gambit was always going to be a temporary fix. The government was unable to define partisan goals, and so it had to justify every reform by reference to the need for shared sacrifice, without having any grassroots organisation to legitimise the sacrifice demanded. The result was that the state, weakened by the fault lines of interest group conflict on which it rests, imposed sacrifices where it could, which did not always make for the perception of shared sacrifice. The government had no natural electoral constituency on which to depend, and austerity policy does not offer an obvious material way to build one. Its source of popularity was the belief in public opinion that there was no alternative to it. Yet democratic government that does not build stronger links to society is of necessity a temporary one, because it has a narrow constituency and few friends.

\section{Italian Capitalism and Interest Groups}

Scholars of capitalism sometimes leave Italy out of their comparative frameworks because the Italian model is so heterogeneous. It comprises internationally competitive large industries and networks of small and medium firms in the north and 
centre of the country. These firms, and the web of institutions that have grown up around them, resemble the coordinated market economies of northern Europe (Soskice 1990; Locke 1995; Culpepper 2007; Hall and Gingerich 2009). However, the union movement is divided along political lines, and that movement has only periodically engaged in cooperation with employers (Simoni 2010). Moreover, the south of Italy has remained unproductive and failed to converge on the north; its primary characteristics are uncompetitive companies and a more prominent role for the public sector, including through state support of unemployed workers. These disparate elements have led some scholars to group Italy with other southern European economies as a mixed market economy, in which states try to substitute for the weaker capacities of unions and employers to coordinate the national political economy (Molina and Rhodes 2007).

On top of this diverse economy with divided interest groups sat a government coalition during the 1980 s comprising five parties of the centre and centre-right, the pentapartito. As Stefano Guzzini (1995: 31) has argued, the functioning of this system depended on 'state resources to finance consensus,' and consequently Italian public debt deteriorated dramatically under the pentapartito. When the party system collapsed after a corruption scandal in 1992, it was replaced by the technocratic government of Carlo Azeglio Ciampi, which ushered in a reform of the electoral system. The Ciampi government of 1993 and the Dini government of 1995 oversaw sweeping fiscal reforms that temporarily stabilised the growth of Italian debt.

This is by now a familiar story to students of Italy and of comparative political economy. Recent scholarship has developed the coalitional underpinnings of the political compromises that took place during this time. The work of Zsofia Barta (2011) models the accumulation of public debt in Italy as a war of attrition between 
four entrenched social groups: large employers in the internationally competitive sector; unionised workers; small firms, especially in the north of the country; and southern beneficiaries of clientelistic state spending. The implosion of the Italian party system during the early 1990 s, combined with increased perception of the need for reform on the part of large employers, made unions and large employers the backbone of a social coalition, which Amable et al. (2012) call a 'producers' coalition.' The group supported the technocratic governments - as well as the first Prodi government elected in 1996 - in attempts to facilitate fiscal retrenchment. This meant, notably, that they shifted the costs of fiscal adjustment onto the members of the opposing social coalition: small employers in the north, who wanted to avoid higher tax bills, and southern workers who wanted to avoid cuts in state spending (Barta 2011). These groups were in political disarray following the collapse of the Christian Democratic Party.

The economic reforms of the 1990s were a product of this unusual period. But the producers' coalition, like the north-south one that opposed it, was internally contradictory. Unions initially had an interest in securing their own prerogatives vis-àvis the COBAS, more radical local competitors (Locke and Baccaro 1996). But their interests in cooperating with each other, and with employers who were interested in further liberalisation, was limited. The left coalition of the late 1990s eventually fell over these tensions. Moreover, viewed longitudinally, this coalition is not majoritarian: the role of large firms in the economy is shrinking in proportion to LMEs, as is the density of the trade unions (DeCecco 2007; Amable et al. 2012).

Many of the structural adjustments that had been undertaken with the support of the producers' coalition and the political left were eroded after 2000, when that coalition collapsed. Confindustria, the peak organisation of employers, became 
increasingly vocal in its calls for liberalisation (Molina and Rhodes 2007). Unions took divergent positions among themselves, reflecting a return to the pre-1992 landscape: divided unions engaged in conflictual bargaining with employers. The right, meanwhile, was caught between the demands of business owners to reduce taxes and those of citizens in the south to maintain public support for the economy. As a result of these internal divisions, the fiscal consolidation undertaken in the 1990s was reversed under the centre-right Berlusconi governments of 2001-2006 and 20082011 (Barta 2011). It remained the case that governments of both left and right had great difficulty collecting taxes; economists estimated the size of the Italian shadow economy at 26 per cent of GDP in 2002-3, second only to Greece (28 per cent) in the OECD. During this period economic growth was sluggish at best, and productivity growth was actually negative in the period after 1999.

Writing about Italy’s northern neighbour, Stanley Hoffmann (1963) observed that the French Third Republic was a regime with "plenty of brakes and not much of a motor.' This observation of the stalemate society resonates in characterising the contemporary political economy of Italy. The major economic reforms of the 1990s took place against the backdrop of an unusual degree of unity within union confederations - and between those unions and organized employers - on the need for changes to the Italian system of economic governance. They were made possible by a temporary political situation in which this social coalition was privileged because the members of the opposing coalition - SMEs from the north and beneficiaries of state largesse in the south - had been politically orphaned by the collapse of the previous Italian party system. These were transitory conditions, and with the emergence of bipolar party competition after 2000, they ceased to hold. This was a system of 
fractious bipolarity, with both left and right beset by internal conflicts between core constituents with different interests.

Before the eurozone crisis ever began, this was the social situation in Italy. And it was against this backdrop that Mario Monti assumed office. His strategy would mark a radical departure from that of the technocratic reformers of the 1990s.

\section{The Monti Programme}

The appointment of Monti's technocratic government in November 2011 was the product of rising pressure on the Italian ability to borrow money to finance itself and a collapse in domestic and international confidence in the capacity of the previous Berlusconi government to stave off this pressure. Pasquino and Valbruzzi summarised the task of the new government as being

to reduce the spread between the Italian and German [sovereign] bonds, to reform and redesign the domestic market to make it more competitive, and to lift the plummeted prestige of Italy in Europe (2012: 619).

Monti, himself a former European commissioner for competition and president of Bocconi University, assembled an entirely non-political cabinet, dubbed the 'government of the professors' by the Italian press. Whereas the past technocratic governments of Ciampi and Dini had relied on backing from the parties of the left, Monti's government clearly saw itself as equally independent of all parties in parliament. The apparent job of the professors was to administer a stern lesson in emergency austerity and liberalising reform, not political compromise.

The government's new programme involved four elements: revenue increases, spending cuts, rationalisation of the state apparatus, and liberalisation of protected 
sectors. The emergency supplementary budget passed in December, Save Italy (Salva Italia), focused on the first three elements of reform, especially weighted toward tax increases. By virtue of the Italian state's unusual tax structure, itself a product of the aforementioned distributive conflicts on the revenue-gathering capacity of the state, many of the most prominent revenue-raising measures came through regressive means. An increase of 25 per cent in gasoline tax took the price to almost $€ 7$ per gallon, the second highest price in the eurozone (Randall 2013). Increases in valueadded tax (VAT), which had been passed by the Berlusconi government but delayed in implementation to avoid political repercussions, also came into force, as did taxes that had previously been waived on owner-occupied first residences. These tax increases affected the entire population, of course, but because of the regressive structure they had proportionally greater impact on those taxpayers of more modest means (Livini 2011). ${ }^{4}$ However, from the point of view of the state they were easily collected.

This was not the case of the luxury taxes included by the Monti government in the Save Italy decree as a way to spread the pain of austerity across the population. The new budget also included measures aimed to reduce tax evasion, such as lowering the amount that could be used for a cash purchase to $€ 1,000$. This measure was accompanied by highly visible raids of the tax police on the playgrounds of wealthy Italians in the winter of 2011, such as the posh ski resort of Cortina and a main shopping street in Milan. Nevertheless, eight months after the passage of Save Italy, the Revenue Service reported that the luxury tax on high-priced cars, boats, and airplanes had generated only $€ 92$ million of the $€ 387$ million predicted. As Monti said in a television interview, 'there are rich and middle-income Italians who systematically do not pay their taxes' (Mobili 2012). Yet tax enforcement continues to 
be a sensitive political issue. In the final act of the government before the elections the Stability Law of 2013 - the government earmarked all income from increased surveillance of tax evasion to go into a fund devoted to the structural reduction of fiscal pressure on firms and families.

On the side of spending cuts, the most important reforms came through changes to the pension system. Government estimates put the savings from the pension reform at $€ 5.4$ billion by 2014, set to rise to more than $€ 20$ billion by 2020 . The reform moved completely to a defined-contribution system (a movement begun in 1995); raised the retirement age for women in the private sector to 62 , which is to increase further until it equals that of men (67) in 2018; and, most severely, removed indexation to inflation for all pensions above the level of $€ 1,400$ per month.

These dramatic changes were not developed, as prior technocratic reforms in Italy had been, through the use of negotiations with the social partners. They were instead the product of pure government intervention. The unions were informed of the content of the reform, but even these meetings took place in bilateral fashion - the government with each union - rather than meeting all unions together with the principal organisation of the employers, Confindustria. The unions were united in their opposition to the controversial attempts to end the indexation of pensions, to raise the minimum retirement age, and to re-impose taxes on the first owner-occupied home. Their concerns led to no government concessions, however; and the result was the calling of a public sector strike that united all three union confederations (UIL, CISL, CIGL). Unlike the attempts of unions to use strikes to bring down the first Berlusconi government in 1994, when that government tried to impose a unilateral pension reform, these strikes had no apparent effect on the Monti government, 
although its approval rating did drop by 16 points from November to December $2011 .^{5}$

In Italy at the time of the decision, there was a widespread sentiment that there was no feasible alternative to Save Italy. This was a reflection of the fact that the country had to borrow to service its debt, and its spread over German ten-year bonds stood at 519 basis points in November, when Monti was appointed. It steadily decreased to 322 basis points by March, a decrease of nearly 40 per cent. Whether or not the Monti government and its Save Italy programme were the only reasons for the initial fall, the public viewed the government as being in a situation of extraordinary, emergency policy-making in December. The Monti government, however, took its December template of non-negotiation as its permanent policy style.

In its two projects for the new year - to liberalise labour and product markets - the government continued to pursue a pattern of reform that rejected the past reliance of technocratic governments on concertation with the social partners. As Monti declared publicly, 'We cannot allow ourselves concertation [with the social partners]... the country cannot allow itself concertation.... These are decisions that must be made in a more modern way' (Galluzzo 2012). The method of the government, in other words, was to listen to the social partners but not to give them a direct policy-making role (Culpepper and Regan 2013). This marked a sharp rejection of the strategy of ongoing concertation undertaken by the Dini government, particularly on divisive social issues in which unions had been perceived to have legitimate stake (Baccaro 2002). For example, during the negotiation of the pension reform in 1995, Labour Minister Tiziano Treu had offered to organise 'non-stop meetings' with the trade unions, noting that 'it is important to reach the necessary consensus [with the trade unions] on such a delicate issue' (Marro 1995). 
Monti's liberalising reforms were substantially less successful - as measured by their ambitions - than were the budgetary changes imposed in Save Italy. Building on the coalitional analysis developed in the previous section, we observe that Monti's reforms frontally assaulted the protections of self-employed professionals (who tended to vote right) and of organised workers (who tended to vote left). Attempts to open markets for taxi drivers, lawyers, and pharmacists to more competition provoked fierce resistance from those groups, leading them to schedule strikes in January and February of 2012. Although a pharmacists' strike cannot bring a city to a halt, these 'strikes' were really expressions of opposition whose target was the political parties they traditionally supported. Thus Silvio Berlusconi's party, the People of Freedom (PdL), explicitly reminded Prime Minister Monti that he had to pass laws through the parliament, where 'a balance of power exists [i.e., a PdL majority] that must be taken into consideration' (Talarico 2012). Against this clear balance of power in parliament, Monti could counter only with the approval rating of his government and his appeal to be able to lower the spread against German bonds - and it is not clear how liberalising the number of taxi licences would have an immediate impact on that front. Each of these groups extracted significant concessions from the government before any law could pass.

In its bid to liberalise the labour market, Monti's government suffered significant reversals after first claiming that negotiations were closed. The two issues of the reform concerned the ease of firing workers (article 18 of the labour code) and the treatment of early retirees in the wake of the pension reform. Article 18 is a symbolically important part of the labour code that forces all firms with more than 15 workers to reinstate those fired if a labour court decides they have been wrongfully dismissed. The mere existence of the article is seen as a brake on firing by companies, 
which view the labour courts as sympathetic to fired workers. After two months of negotiations, the government rejected trade-union protests and said it would proceed without an agreement of the social partners, which excited considerable protest from all trade union confederations. Confindustria welcomed what it called a historic agreement. Public opinion sided with the unions, against the government and the employers: 67 per cent opposed the reform, with only 29 per cent favouring it, with little difference in response between older workers, who are protected, and younger ones whose jobs are more precarious (Jones 2012).

Under sustained lobbying from the (left) Democratic Party and the unions, in the wake of the proclamation of the article 18 reform, Monti then reversed course, softening the reform in favour of workers. This did not satisfy unions, but it enraged Confindustria and the PdL, which supported the employers (Dinmore 2012). The bill that Monti was finally able to get through parliament thus satisfied no one. It allowed labour courts to reinstate workers judged to have been fired for implausible economic grounds. For employers, this left the courts, rather than firms themselves, as the final arbiters of the economic situation of companies. But for unions it represented a slippery-slope concession on a symbolically important article of labour protection.

The second element of reform politics for labour was one that had been created by the pension provisions in Save Italy. By raising the retirement age, the pension reform created a group of workers who had taken early retirement but who were, by virtue of the new rules, not eligible to receive a pension. These workers were called the exiled ones - the esodati - and their ongoing plight challenged the core claimed advantage of the technocratic government: competence. The new government promised to cover the esodati, initially estimating their total number at 65,000 . Outraged unions claimed the number of affected people was 400,000 , and the state's 
social security agency later issued an estimate of 390,000 . The issue of the esodati was the subject of a unitary demonstration in Rome among the three main unions, and the issue of who should be covered, and how, remained controversial throughout the Monti administration. In October, the State General Accounting Department (RGS) rejected a compromise bill on the esodati, charging that the bill had made insufficient financial provisions for the exiled ones (Corriere della Sera 2012).

Mario Monti resigned two months later, in December 2012, after the withdrawal of support of his government by the PdL and the passage of his 2013 budget. At that point, the initial popularity of the government had largely dissipated. Government popularity shows what people think about the government; the spread between long-term German and Italian bonds shows what investors think about the sovereign risk of Italy; and the consumer confidence index shows what Italians think about the state of the economy. ${ }^{6}$ Figure 1 plots these three assessments against each other on a standardised scale from the onset of the eurozone crisis in 2010 to the end of 2012. Notable are the sharp increase of government popularity upon Monti's taking office in November 2011 and the decline of the spread of Italian government bonds over those from Germany during the first five months of the government. If Monti's first job was to lower the government's borrowing costs, he clearly succeeded, at least initially. The subsequent stabilisation of the spread likely had more to do with the interventions of the European Central Bank starting in July 2012.

However, neither the government's popularity nor the fall of the spread appeared to have much of an effect on the confidence of Italians in the overall state of the economy. By May 2012 - at the height of the controversy of the esodati - that confidence reached its lowest level ever recorded since the measure was first taken in 2001, and it more or less remained at that basement level for the rest of 2012. Monti's 
tenure was successful in its stated goal of calming international markets. But the changes made did nothing to restore the belief of Italians in the improvement of the overall economy.

Figure 1: Government Popularity, the Italo-German Bond Spread, and

\section{Consumer Confidence, 2010-2012}

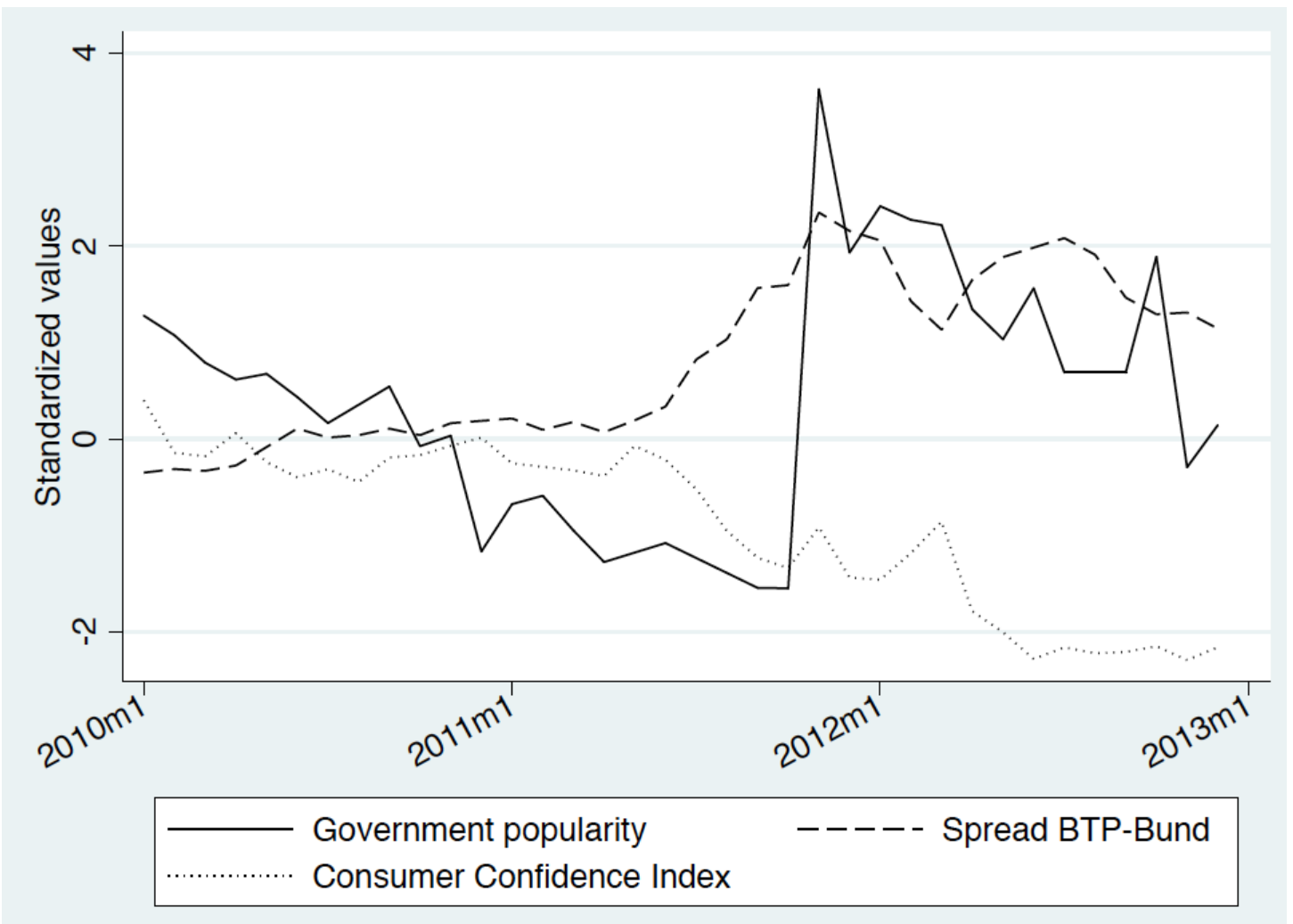

Source: Institute for Economic Studies and Analysis; Federal Reserve Economic

Data; Bellucci and De Angelis (2013).

The end of the government of the professors was not the end of the political lesson of unmediated democracy. The former technocrat surprised the Italian political establishment with his decision to run in the general election that followed his resignation. Monti was supported by the pre-existing centre parties and by a movement led by Luca Montezemolo di Cordero, the former head of Confindustria. 
The Monti coalition won 10.6 per cent of the vote for the lower house in the election held on 24-25 February 2013. This was widely perceived as a failure, including by Monti's supporters. As summarised by Roberto D’Alimonte (2013: 115), From the very beginning of the campaign Monti made clear that he did not want to run as a centrist party seeking to compete on the traditional left- right continuum. His message was centred on the need to reshape the pattern of competition along a new dimension that he identified as change versus status quo. He appealed to the reformers in both camps, the left and the right, in the name of a programme that would continue what he had done as prime minister. Amid a deep economic crisis, and with the legacy of the pension reform and the tax increases his government passed, it was no surprise that his message did not reach a mass audience.

As Monti discovered, the non-party appeal of a reformer 'above politics' was limited. The only group of Italians who voted in large numbers for the Monti list were those living outside of Italy (D'Alimonte 2013: 123-124). It seems that the Monti programme for reforming Italy appeals most to those who do not live there.

\section{The Monti Experiment in Unmediated Democracy}

E. E. Schattschneider (1942: 1) contended that 'modern democracy is unthinkable save in terms of the [political] parties.' The Monti experiment in unmediated democracy suggests the enduring relevance of Schattschneider's observation for those reformers who dream of non-party solutions as the way to unblock the logjam of democratic politics and its fiscal over-commitments. Italy, like its counterparts in the new eurozone periphery - Greece, Ireland, Portugal, and Spain -faced the crisis of the 
euro with political conditions that make reform difficult. The parties of the left and right are themselves representatives of rival social coalitions, none of which is majoritarian: the unionised workforce, large employers, SMEs in northern Italy, and state dependents concentrated in the south (Barta 2011; Amable et al. 2012). The Monti government challenged the privileges of these groups, but the government eventually was forced to yield substantially in its liberalisation aims, because it could not use political parties or interest groups to mobilise support for these reforms.

The government of professors was not a bloodless body of problem-solvers. It was a group of neoliberal reformers whose programme of reform attacked interests of both left and right - the protected sectors of workers and of professionals - in a stalemated economy. Its success depended on the tacit support of parties in parliament, their feet held to the fire of reform by the threat represented by the bond spread. But the democracy was unmediated in the sense that the parties supporting the government were not organising society in favour of the reforms, and the organisations of society (with the exception of the organised employers of Confindustria) were actively mobilised against the reform. When Monti was most successful in pushing through sweeping reform - as he was with the Save Italy budget - was not when voters liked the budget, but when the state of the bond markets left all actors with the sense that there was no choice but to accept a reform that would never have passed in more settled times.

The authority of the Monti government flowed from the top, because it had no roots in society. The government was centrally organised, coordinating bills from the prime minister's office more than a typical Italian government (Marangoni 2012; Pasquino and Valbruzzi 2012). Once the crisis of Italian sovereign bonds became less acute, Monti's ability to impose discipline on this fractured political economy fell 
sharply. The attempt to reform the structure of the state by eliminating provincial governments foundered on the opposition of local representatives of left and right. Berlusconi's party, the PdL, opposed major telecommunications and electoral reforms and defanged anti-corruption legislation that could have threatened its leader. The legitimacy of the government - derived from its professorial cast - took a serious hit when it dramatically underestimated the number of early retirees who would become esodati as a result of the pension reform. And because it worked from the top, without social support, there were few fallbacks to help rebuild the legitimacy of its reform programme.

The previous technocratic government of Lamberto Dini had owed its signal pension reform to its close cooperation with society. Dini's 1995 pension reform was supported by a producers' coalition comprising unions and employers. This coalition had tried to protect its members and to impose costs of fiscal retrenchment on the social groups that had been associated with the parties of the right during the pentapartito (Barta 2011; Amable et al. 2012). As Marco Simoni (2010) argues, the social pact on pensions was part of a temporary agreement among union confederations - normally divided among themselves - with the political parties of the left.

This coalition was not open to Monti, at least not at a price that he would have accepted. He decried the old reforms, negotiated with the unions, as the reason young people could not find a job in today's Italy. And Italian unions themselves, with a shrinking membership of disproportionately older workers, were much less capable of shoring up the legitimacy of governmental reforms than they had been during the 1990s (Culpepper and Regan 2014). The fractious union movement was at its most united only when it protected labour market insiders: the beneficiaries of article 18 
and the esodati, who were early retirees from insider jobs. The unions were unable to articulate alternative proposals that could mobilise large swathes of Italian society about how the costs of austerity might be redistributed.

Monti's budget plan, Save Italy, reversed the distributional pattern of the budgetary stabilisation in the 1990s. Whereas the earlier fiscal retrenchment had hit smaller firms and state dependents especially hard (Barta 2011), the Monti stabilisation aimed more at workers and retirees. However, unlike in the case of Dini and the political left, there was no potential for ongoing cooperation between Monti and the political right, which had interests diametrically opposed to those espoused by the technocratic government: Berlusconi's coalition aimed to minimise tax burdens on SMEs and households, whereas Monti wanted to improve tax collection. And the political right advocated the continuation of state spending in favour of the southern part of the country, whereas Monti wanted to administer extreme austerity to every part of the country. Thus, the technocratic government under Monti could not work with parties on the left and unions, and it could not work with Berlusconi's PdL.

Monti's own social coalition, such as it was, was represented by the Italian centre and Italian big business. Luca Cordero di Montezemolo, the former chairman of Ferrari and of Confindustria, embodied this close link when he became part of Monti's Civic Choice party after the former technocratic prime minister decided to enter partisan politics. The Monti coalition comprised centrists, large employers, and (from abroad) the European Commission. And within this group, even Confindustria complained at times about Monti's exclusion of the social partners from policymaking. This is a coalition rich in resources and in ideas for reform. But it has feeble roots in Italian society. The 10 per cent of the votes gained by the centre parties in the 2013 election represents a fragile electoral base from which to reform Italy. 
Italy is unlikely to be reformed by a government that is not somehow anchored to society through political parties and interest groups. Unmediated democrats, as embodied by the Monti government, may win the support of public opinion during the acute stage of a crisis. This popular approval initially gave the government of the professors the capacity to impose bitter austerity medicine on a stalemated society. But the imposition of durable reforms requires a social coalition to support it beyond the critical stage of crisis. When leaders from the European Union tell Italians their country needs reforms, not elections, those elites misunderstand this fundamental political fact. There is no easy solution for untangling the conflicts that cleave the Italian political economy into a set of fractious minority interests. But there is probably no viable democratic alternative to building a new majoritarian coalition if Italy is to adopt durable economic reforms to return it to the path of growth and prosperity. This coalition may well emerge from the ferment, change, and creative recombination of the social groups active in political parties and interest groups. The Monti experiment suggests it will not be born from a reform plan beloved in Brussels but without substantial support in Italian civil society.

\section{Acknowledgements}

For comments that improved this article the author thanks Mary Louise Culpepper, Stefano Guzzini, Randall Hansen, Duncan McDonnell, Victoria Murillo, two anonymous reviewers, and participants in the conferences on 'Economics and Democracy: Are They Still Compatible?', held at the European University Institute, July 1-3, 2013, and 'Europe's Crisis: Backgrounds, Dimensions, Solutions' held at the University of Toronto, October 12-13, 2012. Andrea de Angelis and Fabio Bulfone provided invaluable research assistance. 


\title{
Endnotes
}

\begin{abstract}
${ }^{1}$ This definition obviously distinguishes what I have in mind by unmediated democracy from Max Weber's concept of unmittelbare Demokratie, which we might translate into English as unmediated democracy but by which he meant what is conventionally referred to as direct democracy (Breiner
\end{abstract} 1996: 186).

${ }^{2}$ This is not to say that the Monti government was undemocratic. It depended for its survival on governing parties in parliament, and Monti himself was able to maintain a relatively high level of popularity in Italian public opinion, even when his austerity plan was unpopular (D'Alimonte 2013).

${ }^{3}$ During the Latin American economic crises of the 1980s and 1990s, when these countries faced internationally imposed pressures similar to those confronting Italy and the other members of the Eurozone periphery, they too chose party governments to distribute the pain of economic reform (Roberts 2013).

${ }^{4}$ Even The Economist, typically a voice in favor of neoliberal reform in Italy, observed at the time that Monti's tax increases fell disproportionately on the lower income groups

(http://www.economist.com/blogs/newsbook/2011/12/italys-budget; accessed 23 April 2014).

${ }^{5}$ The Monti government enjoyed a honeymoon high of 68 per cent approval when it first took office. Even with the 16-point drop in December the government still therefore enjoyed majority approval in December 2011. Thanks to Andrea de Angelis and Paolo Bellucci for government approval ratings data, which is based on a monthly average of nine different polls.

${ }^{6}$ The consumer confidence index is a composite of individual questions asking about the general state
of the economy, the state of particular households, and the employment situation in Italy (Bellucci and De Angelis 2013). 


\section{References}

Amable, Bruno, Elvire Guillaud, and Stefano Palombarini (2012). L’Économie Politique du Néolibéralisme: Le cas de la France et de l'Italie. Paris: Éditions Rue D’Ulm.

Armingeon, Klaus, and Lucio Baccaro (2012). 'The Sorrows of Young Euro: Policy Responses to the Sovereign

Debt Crisis', in Nancy Bermeo and Jonas Pontusson (eds.), Coping with Crisis: Government Responses to the Great Recession. New York: Russell Sage, 162-97.

Avdagic, Sabina (2010). 'When Are Concerted Reforms Feasible? Explaining the Emergence of Social Pacts in Western Europe', Comparative Political Studies, 43:5, 628-57.

Baccaro, Lucio (2002). 'Negotiating the Italian Pension Reform with the Unions: Lessons for Corporatist Theory', Industrial and Labor Relations Review, 55:3, 413-31.

Baccaro, Lucio and Sang-Hoon Lim (2007). 'Social Pacts as Coalitions of the Weak and Moderate: Ireland, Italy and South Korea in Comparative Perspective', European Journal of Industrial Relations, 13:1, 27-46.

Barta, Zsofia (2011). 'Flirting with Disaster: Explaining Excessive Public Debt Accumulation in Italy and Belgium', PhD thesis, London School of Economics.

Bellucci, Paolo and Andrea De Angelis (2013). 'Government Approval in Italy: Political Cycle, Economic Expectations, and TV Coverage', Electoral Studies, 32:3, 452-59.

Breiner, Peter (1996). Max Weber and Democratic Politics. Ithaca, NY: Cornell University Press.

Corriere della Sera. (2012). 'Ddl esodati: 'copertura insufficiente', 9 October.

Culpepper, Pepper D. (2002). 'Power, Puzzling, and "Pacting": The Informational Logic of Negotiated Reforms', Journal of European Public Policy, 9:5, 774-90. 
Culpepper, Pepper D. (2007). 'Eppure, Non Si Muove: Legal Change, Institutional Stability and Italian

Corporate Governance', West European Politics, 30:4, 784-802.

Culpepper, Pepper D. (2008). 'The Politics of Common Knowledge: Ideas and Institutional Change in Wage Bargaining', International Organization, 62:1, 1-33.

Culpepper, Pepper D. and Aidan Regan (2014). 'Why Don't Governments Need Trade Unions Anymore? The Death of Social Pacts in Ireland and Italy', Socio-Economic Review, doi: 10.1093/ser/mwt028.

De Cecco, Marcello (2007). 'Italy’s Dysfunctional Political Economy’, West European Politics, 30:4, 763-783.

Dinmore, Guy (2012). 'Monti under fire as crisis deepens', Financial Times, 6 April.

Galluzzo, Marco (2012). 'Monti: non è più tempo di concertazione.' Corriere della Sera, 21 March.

Garrett, Geoffrey (1993). 'The Politics of Structural Change: Swedish Social Democracy and Thatcherism in Comparative Perspective', Comparative Political Studies, 25:4, 521-47.

Guzzini, Stefano (1995). 'The "Long Night of the First Republic”: Years of Clientelistic Implosion in Italy', Review of International Political Economy, 2:1, 27-61.

Hall, Peter A. and Daniel W. Gingerich (2009). 'Varieties of Capitalism and Institutional Complementarities: An Empirical Analysis', British Journal of Political Science, 39:3, 449-82.

Hoffmann, Stanley (1963). In Search of France. New York: Harper and Row.

Jessoula, Matteo and Tiziano Alti (2010). 'Italy: An Uncompleted Departure from Bismarck', in Bruno Palier (ed.), A Long Goodbye to Bismarck? The Politics of Welfare Reform in Continental Europe. Amsterdam: Amsterdam University Press, 157-81.

Jones, Gavin (2012). 'Monti’s labour reform rejected by those it aims to help.' Reuters, 27 March. 
Karremans, Johannes (2014). 'State Interests versus Citizens’ Preferences: On Which Side Do Parties Stand?', unpublished manuscript, European University Institute.

Livini, Ettore (2011). 'Addizionali, Imu sulla casa, Iva, benzina tasse e rincari da 600 euro a famiglia', La Repubblica 6 December.

Locke, Richard and Lucio Baccaro (1996). 'Learning from past mistakes? Recent Reforms in Italian Industrial Relations', Industrial Relations Journal, 27:4, 289-303.

Mair, Peter (2009). 'Representative versus Responsible Government', Max Planck Institute for the Study of Societies Working Paper, 09/8.

Marangoni, F. (2012). 'The Legislative Activity of Technocrats: An Updating of Indicators at the (Early) End of the Monti Government', Bulletin of Italian Politics, 4:2, 295-303.

Marro, Enrico (1995). 'Pensioni, si tratta a oltranza.' Corriere della Sera, 4 March.

McDonnell, Duncan and Marco Valbruzzi (2014). 'Defining and Classifying Technocrat-led and Technocratic Governments’ European Journal of Political Research, doi: 10.1111/1475-6765.12054.

Mobili, Marco (2012). 'Le tasse sul lusso non decollano', Il Sole 24 Ore, 18 August.

Molina, Oscar and Martin Rhodes (2007). 'Industrial Relations and the Welfare State in Italy: Assessing the Potential of Negotiated Change', West European Politics, 30:4, 803-29.

Natali, David and Martin Rhodes (2005). 'The Berlusconi Pension Reform and the Emerging “Double Cleavage" in Distributive Politics', Italian Politics, 20, 172-89.

Pasquino, Gianfranco (2007). 'The Five Faces of Silvio Berlusconi: The Knight of Anti-Politics', Modern Italy, $12: 1,39-54$. 
Pasquino, Gianfranco and Marco Valbruzzi (2012). ‘Non-partisan Governments Italian-style: Decision-making and Accountability', Journal of Modern Italian Studies, 17:5, 612-29.

Randall, Tom (2013). 'Highest and Cheapest Gas Prices Per Country.' Bloomberg.com, 13 February. Available at http://www.bloomberg.com/slideshow/2013-02-13/highest-cheapest-gas-prices-by-country.html\#slide5 (accessed 23 April 2014).

Regini, Marino (2000). 'Between Deregulation and Social Pacts: The Responses of European Economies to Globalization', Politics \& Society, 28:1, 5-33.

Rhodes, Martin (1998). ‘Globalization, Labour Markets, and Welfare States: A Future of "Competitive Corporatism?", in Martin Rhodes and Yves Mény (eds.), The Future of European Welfare: A New Social Contract? London: Macmillan, 178-203.

Roberts, Kenneth M. (2013). 'Market Reform, Programmatic (De)alignment, and Party System Stability in Latin America', Comparative Political Studies, 46:11, 1422-52.

Schattschneider, E. E. (1942). Party Government: American Government in Action. New York: Rinehart \& Co.

Schmidt, Vivien and Elisabetta Gualmini (2013). 'The Political Sources of Italy's Economic Problems: Between Opportunistic Political Leadership and Pragmatic, Technocratic Leadership', Comparative European Politics, $11: 3,360-82$.

Simoni, Marco (2010). 'Labour and Welfare Reforms: The Short Life of Labour Unity', in A. Mammone and G. A. Veltri (eds.), Italy Today. The Sick Man of Europe, London: Routledge.

Soskice, David (1990). 'Wage Determination: The Changing Role of Institutions in Advanced Industrialized Countries', Oxford Review of Economic Policy, 6:4, 36-61.

Talarico, Rosaria (2012). 'Governo I fronti aperti', La Stampa, 23 January. 